The Velocity of Money and the Stock Market. A Comparative Forward ...

Dr. Ashraf Helmy Salama

\title{
The Velocity of Money and the Stock Market. A Comparative Forward and Backward Analysis
}

\section{Ashraf Helmy Salama}

Associate Professor of Economics, Egyptian Chinese University, Faculty of Economics and International Trade, Cairo, Egypt.

ORCDI: 0000-0001-7543-8785

e-mail: ahelmy@ecu.edu.eg

\section{Abstract}

This study applied the panel autoregressive distributed lag (ARDL) model to examine the forward and backward relationships between the velocity of money and the traded stocks in samples of economies varies in term of the level of money supply relative to nominal GDP and the level of economic development during the period 2000-2019.

The empirical findings show differentiated mutual relationships and degrees of response between the velocity of money and the value of traded stocks for each level of money supply relative to GDP and each level of economic development. For developed economics, the value of traded stocks highly and positively responds to the velocity of money and the velocity of money encourages the value of traded stocks. The degree of the positive response of the value of traded stocks to the velocity of money is 
The Velocity of Money and the Stock Market. A Comparative Forward ...

Dr. Ashraf Helmy Salama

relatively low in developing economies, and the value of traded stocks discourages the velocity of money in these economies. The response of the value of traded stocks to the velocity of money is negative in economies with high levels of money supply relative to their nominal GDP; the velocity of money negatively affects the value of traded stocks. As long as the level of the money supply is lying beneath the level of nominal GDP, the value of traded stocks responds positively and highly to the velocity of money. Finally, the effect of the velocity of money on the traded stocks is much stronger than the effect of traded stocks on the velocity of money.

Keywords: Stocks, velocity of money, money supply, economic development.

\section{JEL: D53, E31, E44, E51, O12.}

\section{Introduction}

The successful interactions between the real and monetary sectors are crucial for achieving sustainable economic growth. The ideal mutual relationship states that each sector should support the other one to ensure sustainable economic growth. On one hand, the transactions in the real sector support and encourage real investment, which, in turn, stimulates the monetary sector to finance the increasing investment spending. On the other hand, an active and efficient financial system supports the real sector with multiple ways 
The Velocity of Money and the Stock Market. A Comparative Forward ...

Dr. Ashraf Helmy Salama

and instruments to finance the investment spending (Baumol and Blinder, 2003). However, the empirical experiments don't necessarily match with this ideal mutual relationship. Empirically, several causality relationships are expected, one-sided positive relationship, one-sided negative relationship, interdependence relationship, and no causal relationship (Mujeri and Mujeri, 2020). The velocity of money is one indicator regarding the performance and the stability of the real sector. High levels of risk or uncertainty about the real sector are usually associated with low rates of velocity of money, and as the real sector becomes more stable and trusted, the velocity of money starts to increase (Friedman, 1984). There is a causality relationship between the velocity of money and business cycles where the unbalanced velocity of money may cause inflation or recession (Alikhanov and Taylor 2015; LEÃO, 2005; Komijani and Nazarian, 2004); thus, a balanced velocity of money is considered a key tool to ensure the stability of the price level and rapid and sustained economic growth in any economy (Akinlo, 2012), where the velocity of money is considered the link that connects the money supply and the real economy (Yua, 2013). In other words, both the money supply and the velocity of money are responsible for the spending status in the economy and energizing the real sector (Gentle and Jones, 2015). This makes the velocity of money of potential impact on the stock market, which is in a mutual relationship with the performance of the real sector (Westerhoff, 2011). 
The Velocity of Money and the Stock Market. A Comparative Forward ...

Dr. Ashraf Helmy Salama

\subsection{Study Problem}

While both the money supply and the velocity of money are responsible for the spending status in the economy and energizing the real sector; however, the money supply is under the direct control of the monetary authority while the velocity of money is not. In other words, the monetary authorities are able to affect the velocity of money just through indirect channels. In this context, determining the different economic circumstances that may alter the mutual relationship between the velocity of money and the value of traded stocks enable for identifying these indirect channels.

\subsection{Study Objectives and Layout}

This study tries to examine the forward and backward relationships between the velocity of money, one of the tools that stimulate the real sector, and the value of traded stocks, one of the performance indicators on the financial system, under different levels of money supply and economic development. Figure (1) illustrates the study layout. 
The Velocity of Money and the Stock Market. A Comparative Forward ...

Dr. Ashraf Helmy Salama

Figure (1): The Study Layout

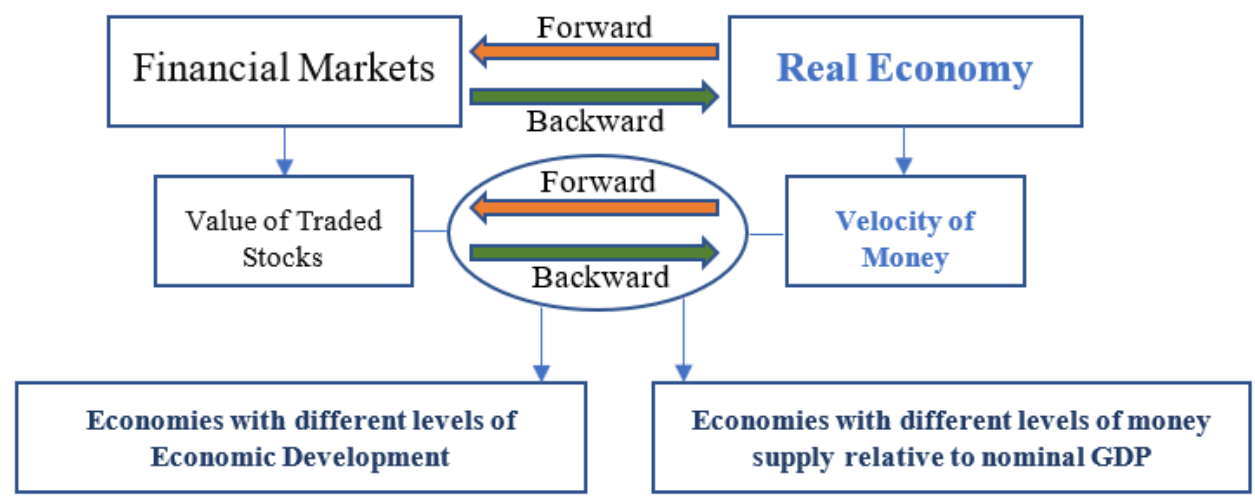

\subsection{Study Hypotheses}

-The mutual relationships between the value of traded stocks and the velocity of money differ according to the level of money supply relative to the level of nominal GDP.

- The mutual relationships between the value of traded stocks and the velocity of money differ according to the level of economic development.

- The forward impact of the velocity of money to the value of the traded stocks is stronger than the backward impact of the relationship.

\subsection{Study Methodology}

This study applied the panel autoregressive distributed lag (ARDL) model, Akaike info criterion (AIC), on panel data in 
The Velocity of Money and the Stock Market. A Comparative Forward ...

Dr. Ashraf Helmy Salama

their logarithm forms to determine the mutual elasticity and relationship between the velocity of money and the value of traded stocks.

\subsection{The scope of the study}

This study examines the mutual relationships between the value of traded stocks and the velocity of money in two categories of economies during the period 2000-2019. The first category includes two sample economies, and each sample includes 8 economies classified due to the level of money supply relative to nominal GDP. The second category includes two sample economies, and each sample includes 9 economies classified due to the level of economic development.

\subsection{Sources of Data}

Data are collected from the World Development Indicators of the World Bank.

\subsection{Research Plan}

Section (1): Introduction.

Section (2): Literature Review.

Section (3): The Development of Velocity of Money and Value of Traded Stocks in the Sample Countries.

Section (4): Econometric Analysis and Empirical Findings.

Section (5): Concluding Remarks and Recommendations. 
The Velocity of Money and the Stock Market. A Comparative Forward ...

Dr. Ashraf Helmy Salama

\section{Literature Review}

There are multiple number of literatures that empirically examined the determinants and factors that affect the velocity of money.

The study of Mohamed (2020) isolated the effect of institutional factors and applied cointegration and error correction methods to examine the relationship between the velocity of money and a number of economic variables in Sudan during the period 19692016. The study argued that economic growth, trade openness, and government deficit stimulate the velocity of money, while inflation and investment spending discourage the velocity of money. The study of Sharma and Syarifuddin (2019) applied ARDL model on monthly data for the period 2000-2017 to identify the determinants of the velocity of money in Indonesia in the long and short run. The study debated that tax proceeds, industrial output, and short-term interest rates affect the velocity of money in the long run while demand for money affects the velocity of money in the short run. The study of Nunes et al. (2018) applied cointegration autoregression test on time series data for the period 1891-1998 to determine the behavior of the velocity of money and examine the effect of macroeconomic variables and institutional factors on the velocity of money in the Portuguese economy. The study found that institutional factors have significant long-run effects on the velocity of money, and macroeconomic variables such as levels of income, interest rates, and inflation rates scientifically affect the velocity of money as

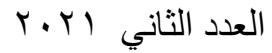

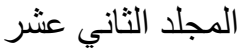


The Velocity of Money and the Stock Market. A Comparative Forward ...

Dr. Ashraf Helmy Salama

well. Moreover, the effect of institutional factors on the velocity of money follows a $U$ shape trend with a late turning point. The study of Aruna (2016) applied ARDL model to examine the effect of financial development, represented by the financial development index, on the velocity of money in Sierra Leone through the period 1970-2013. The study argued that the financial development in Sierra Leone did not affect the velocity of money, indicating that poor financial development efforts have been in place through the considered period. The study of Nampewo and Opolot (2016) applied ARDL model to examine the effect of financial innovations on the velocity of money in Uganda during the period 2000-2013. The study illustrated financial development has had a negative impact on the velocity of money in the short run and turned into a positive impact in the long run. The study of Ng'imor (2015) utilized the ARDL and the stepwise regression analysis to determine factors that affect the velocity of money in Kenya through the period 1998-2012. The study determined real GDP with a positive effect on the velocity of money while the real exchange rate and the growth of the financial sector negatively affect the velocity of money. The study of Okafor (2013) utilized the Vector Autoregressive model to identify main determinants of income velocity of money in Nigeria during the period 1985-2012 and argued that the growth of income and interest rate positively affect the velocity of money while there is a negative relationship between stock 
The Velocity of Money and the Stock Market. A Comparative Forward ...

Dr. Ashraf Helmy Salama

market capitalization and the velocity of money. The study of Akinlo (2012) used multivariate co-integration and error correction modeling approach to examine the effect of financial development on the velocity of money in Nigeria through the period 1986-2010 and argued that exchange rate devaluation negatively affects the velocity of money; in contrary, per capita income stimulates the velocity of money. In addition, the relationship between financial development and the velocity of broad money is a long-run relationship. The study of Sudo (2011) investigated the factors that stand behind the decline in the velocity of money during the period 1990-2010 in Japan and argued that the discount factor and liquidity requirement determined by the households are the main influencers to the velocity of money. The study of Rami (2010) applied the ARDL model to examine the determinants of the velocity of money in India through the period 1972-2004. The study determined institutional factors such as the population of the banking system and the level of monetization as main influencers of the velocity of money. The study of Zhao and Wang (2006) applied ordinary regression analysis to examine the sectoral effect on the velocity of money through the period 1979-2003. The study argued that the relative weights of different productive sectors affect the velocity of money and that the decrease in the velocity of money in China is attributed to the decreases in the relative weight of the agriculture sector. 
The Velocity of Money and the Stock Market. A Comparative Forward ...

Dr. Ashraf Helmy Salama

Despite there are several pieces of literature that cover the factors affecting the velocity of money; however, I found just one literature that covers the backward effect of the velocity of money on different variables in the economy. The study of Warburton (2013) applied the Newey-West estimator and logit estimator to determine factors managed to stimulate the economy during the period 19572011. The study argued that the velocity of money is one crucial factor to encourage economic growth during recession periods when financial and real markets fail in doing so.

What is new with this study?

This study tries to examine the forward and backward relationships between the value of traded stocks and the velocity of money and, unlike the majority of literature that focused on one country only, the scope of this study expands to include several economies and the analysis of panel data, not just time-series data of a certain economy. Moreover, the relationships between the velocity of money and the value of traded stocks will be examined with different levels of money supply and economic development.

\section{The Development of Velocity of Money and Value of Traded Stocks in the Sample Countries}

3.1. Countries with Different Levels of Money Supply Relative to Nominal GDP

This category is classified into two country samples. The first sample includes countries with levels of money supply exceed 
The Velocity of Money and the Stock Market. A Comparative Forward ...

Dr. Ashraf Helmy Salama

their nominal GDP (high liquidly sample), while the second sample includes countries with money supply equals to $70 \%$ or less of their nominal GDP (low liquidity sample).

\subsubsection{High Liquidity Countries Sample}

This sample contains 8 countries, namely China, Hong Kong, Japan, Jordon, Korea, Malaysia, Singapore, and Thailand. The development of the velocity of money of these countries through the two sub-periods 2000-2010 and 2011-2019 is represented by figure (2).

Figure (2): Development of the Velocity of Money in the High Liquidity Countries Sample

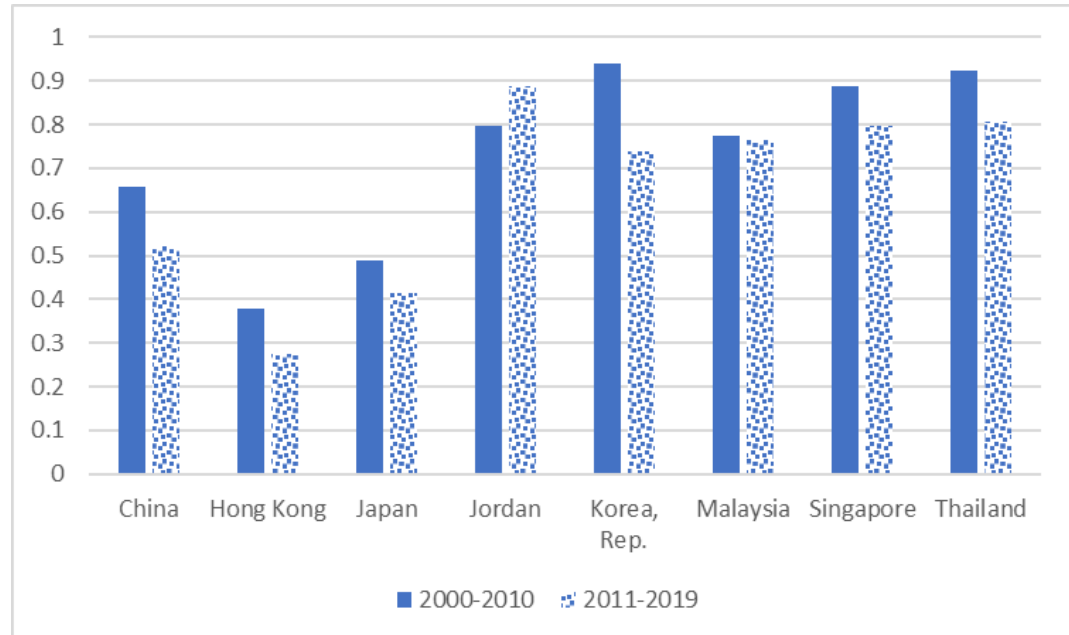

Source: Author's calculations based on World Bank, World Development Indicators Data Base.

Figure (2) illustrates the development of the average velocity of money of the high liquid countries. The velocity of money of all 
The Velocity of Money and the Stock Market. A Comparative Forward ...

Dr. Ashraf Helmy Salama

countries in the sample did not exceed or even reach number one. Besides, the second sub-period witnessed relative retreatment in the velocity of money for all countries in the sample except Jordan.

The development of the value of traded stocks in the high liquidity countries sample is represented by table (1) and figure (3). The value of traded stocks has been rapidly grown for all the countries in the sample except Jordan.

Table (1): The Development of the Average Value of Traded Stocks in High

Liquidity Countries Sample (Billion US\$)

\begin{tabular}{|c|c|c|c|c|c|c|c|c|}
\hline Period & China & Hong Kong & Japan & Jordan & Korea & Malaysia & Singapore & Thailand \\
\hline $2000-2010$ & 2755 & 830 & 3861 & 11 & 1036 & 68 & 176 & 97 \\
\hline $2011-2019$ & 15357 & 1633 & 5174 & 3 & 1775 & 126 & 217 & 312 \\
\hline
\end{tabular}

Source: World Bank, World Development Indicators Data Base.

Figure (3): Growth Rates of the Value of Traded Stocks in the High

Liquidity Countries Sample

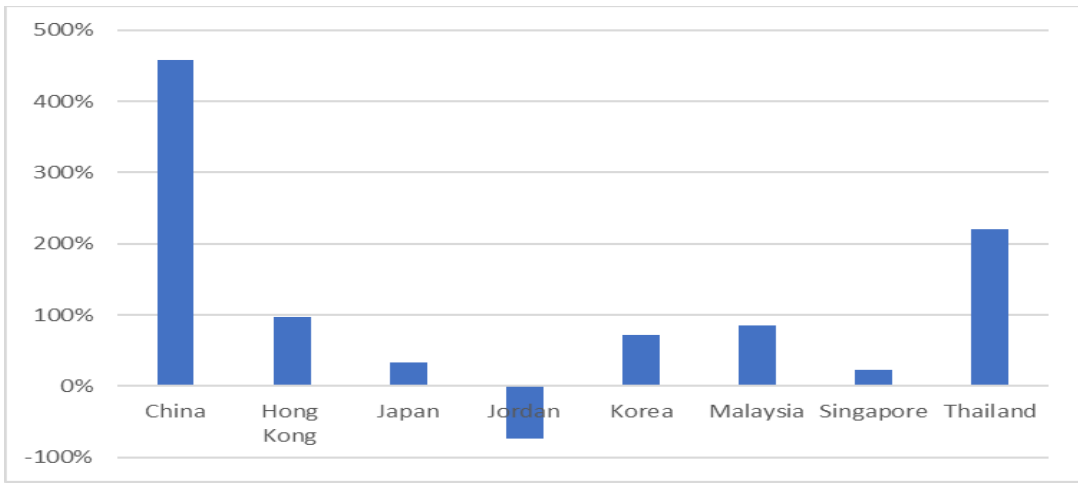

Source: Author's calculations based on World Bank, World Development Indicators Data Base. 
The Velocity of Money and the Stock Market. A Comparative Forward ...

Dr. Ashraf Helmy Salama

\subsubsection{Low Liquidity Countries Sample}

This sample contains 8 countries, namely Colombia, Indonesia, Mexico, Peru, Poland, Russian Federation, Sri Lanka, and Turkey. The development of the velocity of money of these countries through the two sub-periods 2000-2010 and 2011-2019 is represented by figure (4).

Figure (4): Development of the Velocity of Money in the Low Liquidity

Countries Sample

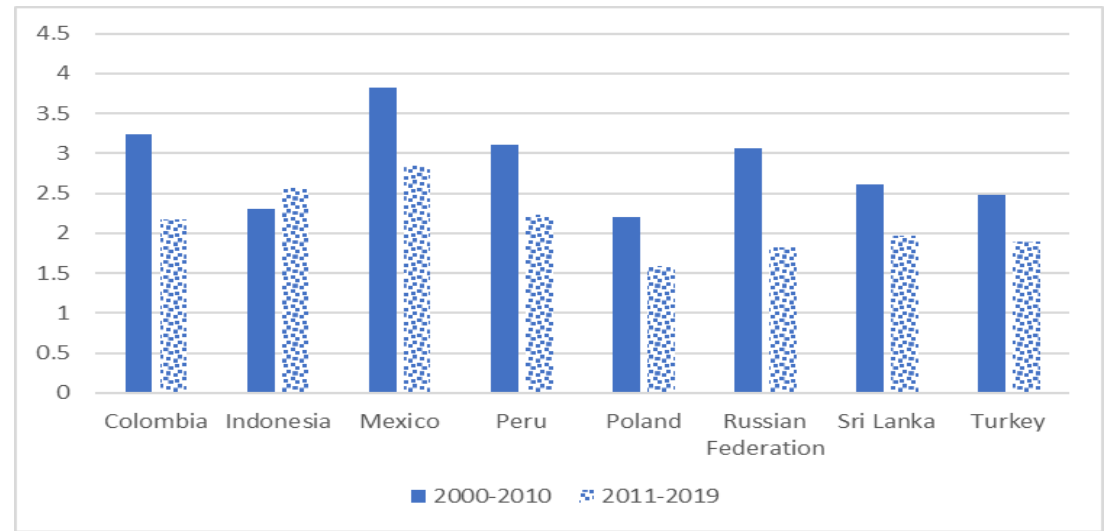

Source: Author's calculations based on World Bank, World Development Indicators Data Base.

Figure (4) illustrates the development of the average velocity of money of the low liquid countries. The velocity of money of all countries in the sample is very high: however, the second subperiod witnessed relative retreatment in the velocity of money for all countries in the sample except Indonesia.

The development of the value of traded stocks in the low liquidity countries sample is represented by table (2) and figure 
The Velocity of Money and the Stock Market. A Comparative Forward ...

Dr. Ashraf Helmy Salama

(5). The value of traded stocks has been significantly grown for all the countries in the sample except Russian Federation.

Table (2): The Development of the Average Value of Traded Stocks in Low Liquidity Countries Sample (Billion US\$)

\begin{tabular}{|c|c|c|c|c|c|c|c|c|}
\hline Period & Colombia & Indonesia & Mexico & Peru & Poland & $\begin{array}{c}\text { Russian } \\
\text { Federation }\end{array}$ & Sri Lanka & Turkey \\
\hline 2000-2010 & 9.9 & 45.4 & 65.3 & 2.8 & 37 & 407 & 1.1 & 203 \\
\hline $2011-2019$ & 17.9 & 96.4 & 112.7 & 3.4 & 59.5 & 224.5 & 1.8 & 354.5 \\
\hline
\end{tabular}

Source: World Bank, World Development Indicators Data Base.

Figure (5): Growth Rates of the Value of Traded Stocks in the Low Liquidity Countries Sample

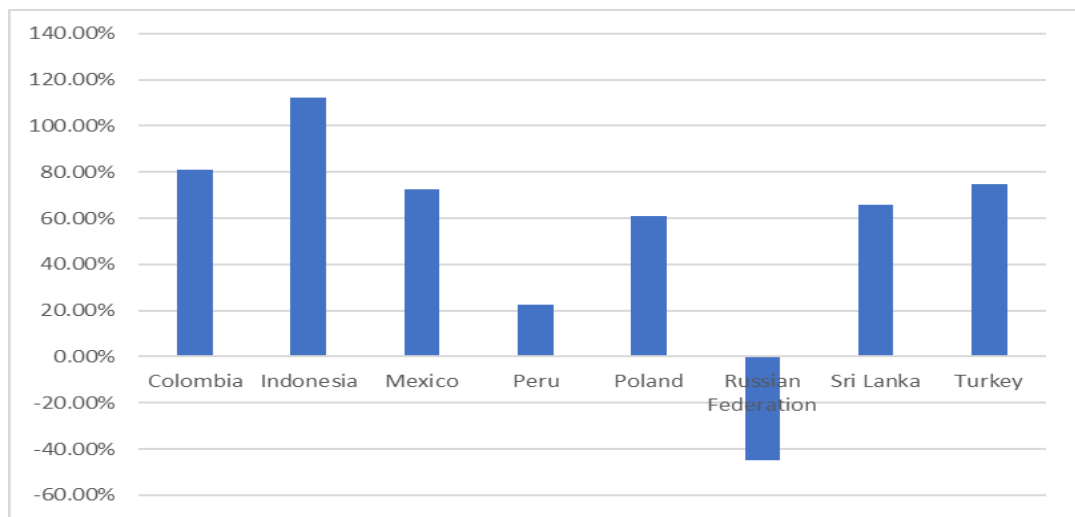

Source: Author's calculations based on World Bank, World Development Indicators Data Base.

\subsection{Countries with Different Levels of Economic Development}

This category is classified into two country samples. The first sample includes countries with advanced levels of economic development (OECD countries sample), while the second sample 
The Velocity of Money and the Stock Market. A Comparative Forward ...

Dr. Ashraf Helmy Salama

includes countries with relatively modest levels of economic development (developing countries sample).

\subsubsection{The Developed Countries Sample}

This sample contains 9 of the OECD member countries, namely Australia, Chile, Colombia, Israel, Japan, Korea, Mexico, Turkey, and the United States. The development of the velocity of money of these countries through the two sub-periods 20002010 and 2011-2019 is represented by figure (6).

Figure (6): Development of the Velocity of Money in the Developed Countries Sample

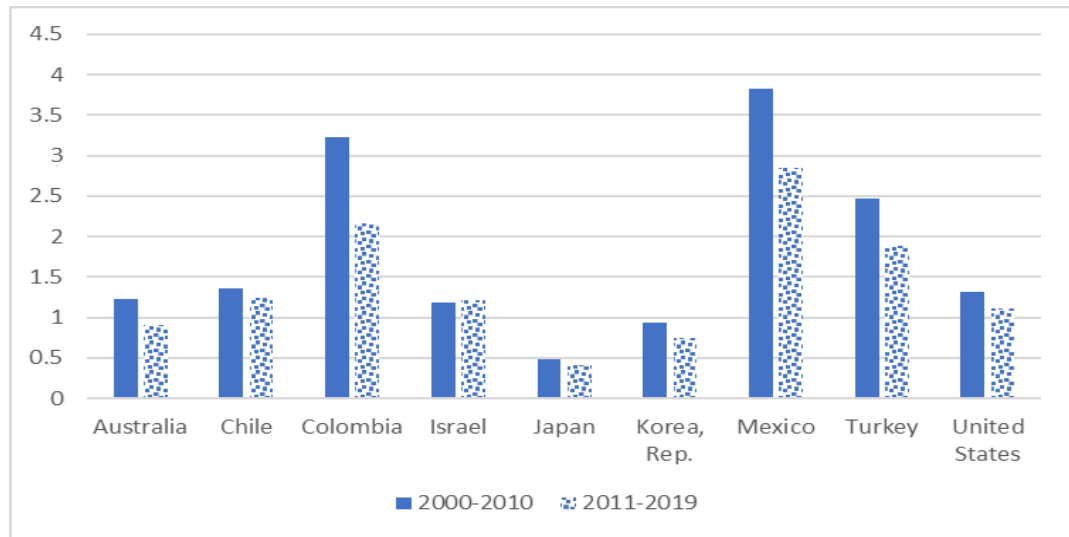

Source: Author's calculations based on World Bank, World Development Indicators Data Base.

Figure (6) illustrates the development of the average velocity of money of the developed countries. The velocity of money significantly varies between the sample countries and ranging from 
The Velocity of Money and the Stock Market. A Comparative Forward ...

Dr. Ashraf Helmy Salama

0.5 to 3.7. In addition, the velocity of money tended to diminish in the second sub-period for all countries in the sample except Israel.

The development of the value of traded stocks in the developed countries sample is represented by table (3) and figure (7). The value of traded stocks has been significantly grown for all the countries in the sample.

Table (3): The Development of the Average Value of Traded Stocks in the

Developed Countries Sample (Billion US\$)

\begin{tabular}{|c|c|c|c|c|c|c|c|c|c|}
\hline Period & Australia & Chile & Colombia & Israel & Japan & Korea, & Mexico & Turkey & $\begin{array}{c}\text { United } \\
\text { States }\end{array}$ \\
\hline $\begin{array}{c}2000- \\
2010\end{array}$ & 670 & 23 & 10 & 54 & 3861 & 1036 & 65 & 203 & 29061 \\
\hline $\begin{array}{c}2011- \\
2019\end{array}$ & 832 & 36 & 18 & 60 & 5174 & 1775 & 113 & 354 & 36122 \\
\hline
\end{tabular}

Source: World Bank, World Development Indicators Data Base.

Figure (7): Growth Rates of the Value of Traded Stocks in the Developed Countries Sample

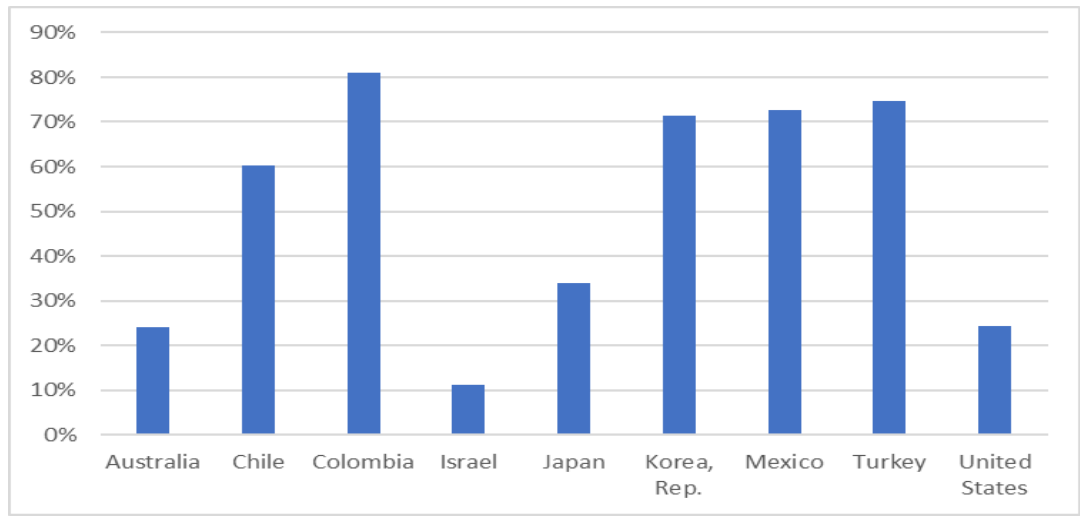

Source: Author's calculations based on World Bank, World Development Indicators Data Base. 
The Velocity of Money and the Stock Market. A Comparative Forward ...

Dr. Ashraf Helmy Salama

\subsubsection{The Developing Countries Sample}

This sample contains 9 countries, namely Brazil, Croatia, Indonesia, Mauritius, Peru, Philippines, South Africa, Sri Lanka, and Thailand. The development of the velocity of money of these countries through the two sub-periods 2000-2010 and 2011-2019 is represented by figure (8).

Figure (8): Development of the Velocity of Money in the Developing

Countries Sample

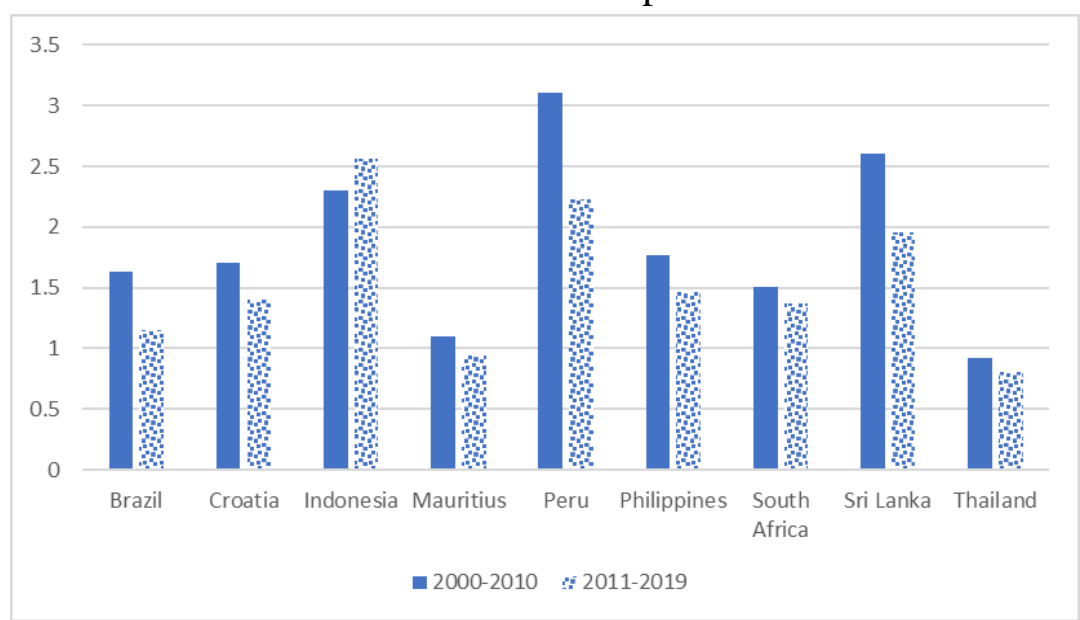

Source: Author's calculations based on World Bank, World Development Indicators Data Base.

Figure (8) illustrates the development of the average velocity of money of the developing countries. The velocity of money of the sample countries varies in the range 0.7 and 3.1 and the second sub-period witnessed relative retreatment in the velocity of money for all countries in the sample except Indonesia. 
The Velocity of Money and the Stock Market. A Comparative Forward ...

Dr. Ashraf Helmy Salama

The development of the value of traded stocks in the developing countries sample is represented by table (4) and figure (9). The value of traded stocks has been significantly grown for all the countries in the sample except Croatia.

Table (4): The Development of the Average Value of Traded Stocks in the

Developing Countries Sample (Billion US\$)

\begin{tabular}{|c|c|c|c|c|c|c|c|c|c|}
\hline Period & Brazil & Croatia & Indonesia & Mauritius & Peru & Philippines & $\begin{array}{c}\text { South } \\
\text { Africa }\end{array}$ & $\begin{array}{c}\text { Sri } \\
\text { Lanka }\end{array}$ & Thailand \\
\hline $\begin{array}{c}2000- \\
2010\end{array}$ & 333.1 & 1.3 & 45.4 & 0.2 & 2.8 & 9.6 & 138.8 & 1.1 & 97.1 \\
\hline $\begin{array}{c}2011- \\
2019\end{array}$ & 690.3 & 0.5 & 96.4 & 0.4 & 3.4 & 35.2 & 284.1 & 1.8 & 311.6 \\
\hline
\end{tabular}

Source: World Bank, World Development Indicators Data Base.

Figure (9): Growth Rates of the Value of Traded Stocks in the Developing Countries Sample

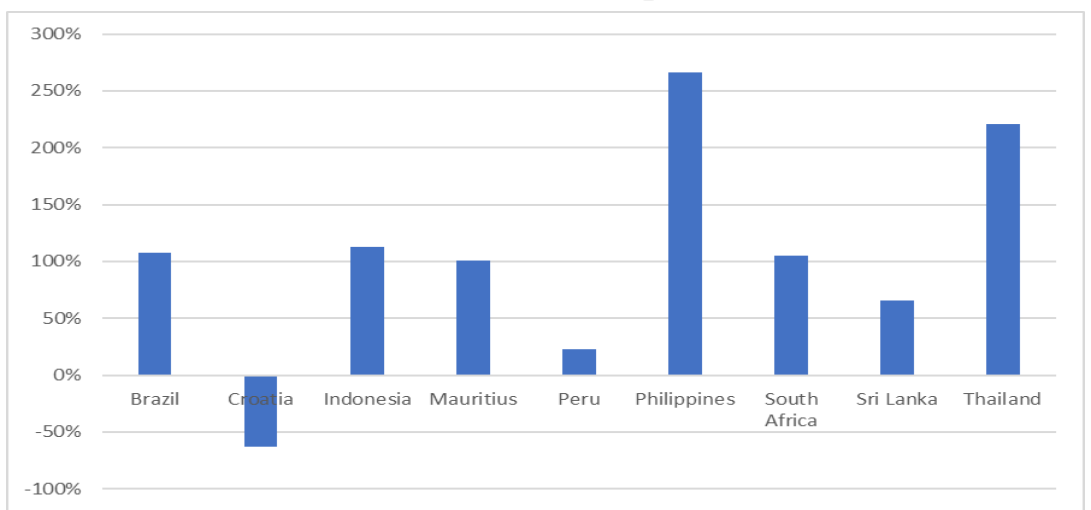

Source: Author's calculations based on World Bank, World Development Indicators Data Base. 
The Velocity of Money and the Stock Market. A Comparative Forward ...

Dr. Ashraf Helmy Salama

\section{Econometric Analysis and Empirical Findings}

This section examines the mutual relationship between the value of traded stocks and the velocity of money in the previously mentioned two categories of economies by applying the panel autoregressive distributed lag (ARDL) model, Akaike info criterion (AIC).

\subsection{Specifying the Model}

The generalized autoregressive distributed lag (ARDL) model has been built based on the following function:

$$
y_{n t}=f\left(y_{n, t-k}, x_{n t}, x_{n, t-v}\right)
$$

Where $y$ and $\mathrm{x}$ are the total value of traded stocks and the velocity of money, reciprocally, $k$ represents the lags of the dependent variables, $v$ represents the lags of the independent variables or the regressors.

The generalized model is represented as follows:

$$
\ln y_{n t}=\sum_{k=1}^{K} \Theta_{n} \ln y_{n, t-k}+\sum_{v=0}^{V} \beta_{n, t-v} \ln x_{n, t-v}+\varphi_{n}+\varepsilon_{n t}
$$

Where $\Theta$ represents the coefficients of the lagged dependent variables, $\beta$ represents the coefficients of the independent variables, $\varphi$ represents the unit-specific fixed effect, and $\varepsilon$ represents the error term. 
The Velocity of Money and the Stock Market. A Comparative Forward ...

Dr. Ashraf Helmy Salama

The error correction model or the re-parameterized ARDL model is represented as follows:

$\Delta \ln y_{n t}=\theta_{n}(\underbrace{\ln y_{n, t-1}-\psi_{n} \ln x_{n t}})+\sum_{k=1}^{K-1} \xi_{n t} \Delta \ln y_{n, t-k}+\sum_{v=0}^{V-1} \beta_{n t}^{\prime} \ln \Delta x_{n, t-v}+\varphi_{n}-\varepsilon_{n t}$

Error Correction Term

Where $\theta$ is the coefficient of the error correction term and it indicates the speed of correcting the short-term deviations, $\psi$ represents the long-run relationships vector, $\xi$ and $\beta^{\prime}$ are the short-term dynamic coefficients.

\subsection{Stationarity Test}

Augmented Dickey-Fuller and Phillips-Perron tests have been used to examine the stationarity of the model variables. The test revealed that all the model variables are stationary, whether at level or the first difference, see appendix (1).

4.3. The Empirical Findings Regarding the Level of Money Supply relative to GDP

The outcomes of the ARDL models indicate that the model is valid where, the coefficients of the error correction terms are negative and statistically significant at a $1 \%$ significance. Then, causal long-run relationships are running from the regressors to the dependent variables, see appendices (2), (3), (4), and (5). 
The Velocity of Money and the Stock Market. A Comparative Forward ...

Dr. Ashraf Helmy Salama

4.3.1. Countries with Levels of Money Supply higher than Nominal GDP

For countries with high levels of money supply relative to their nominal GDP, the velocity of money is found with a negative impact on the value of traded stocks, where the coefficient of the velocity of money is -3.22 and it is statistically significant at a $1 \%$ significance level. In other words, the response of the value of traded stocks to changes in the velocity of money is elastic and negative, see appendix (2). On the other hand, the response of the velocity of money to changes in the value of traded stocks is inelastic and negative, see appendix (3).

4.3.2. Countries with Levels of Money Supply less than Nominal GDP

For countries with low levels of money supply relative to their nominal GDP, the velocity of money positively affects the value of traded stocks, where the coefficient of the velocity of money is 7.2 and it is statistically significant at a $1 \%$ significance level. This indicates that the response of the value of traded stocks to changes in the velocity of money is elastic and positive, see appendix (4). On the other side, the response of the velocity of money to changes in the value of traded stocks is inelastic and negative, see appendix (5).

العدد الثاني Y.r.

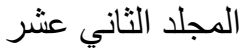


The Velocity of Money and the Stock Market. A Comparative Forward ...

Dr. Ashraf Helmy Salama

4.4. The Empirical Findings Regarding the Level of Economic Development

The outcomes of the ARDL models indicate that the model is valid where, the coefficients of the error correction terms are negative and statistically significant at a $1 \%$ significance level. Then, causal long-run relationships are running from the regressors to the dependent variables, see appendices (6), (7), (8), and (9).

\subsubsection{Sample of OECD Countries}

The velocity of money supports the stock market in countries with advanced levels of development where the response of the value of traded stocks is elastic and positive to the velocity of money. The coefficient of the value of traded stocks is 14.8 and it is statistically significant at a $1 \%$ significance level, see appendix (6). Moreover, the thriving stock trade increases the velocity of money; however, the response of the velocity of money to changes in the value of traded stocks is inelastic, see appendix (7).

4.4.2. Sample of Countries with Modest Levels of Development

For countries with relatively modest and low levels of development, the response of stock market to the velocity of money is positive, where the coefficient of the value of traded stocks is 6.65 and it is statistically significant at a $1 \%$ significance level, see appendix (8). In contrary, the effect of the value of traded stocks on the velocity of money is negative and the response of the velocity of money is inelastic, where the 
The Velocity of Money and the Stock Market. A Comparative Forward ...

Dr. Ashraf Helmy Salama

coefficient of the velocity of money is -0.066 and it is statistically significant at a $1 \%$ significance level.

\section{Concluding Remarks and Recommendations}

The empirical findings of the study illustrate that the mutual effect of the value of traded stocks and the velocity of money depends on both the level of money supply relative to nominal GDP and the level of economic development.

As long as the level of money supply exceeds the level of nominal GDP the mutual relationship between the value of traded stocks and the velocity of money is negative, and as the level of money supply falls beneath the level of GDP the effect of the velocity of money on the value of traded stocks became positive; however, the velocity of money negatively affects the value of traded stocks. On the other side, the velocity of money and the value of traded stocks encourage and support each other in the developed countries. For developing countries, the value of traded stocks supports the velocity of money; however, the opposite is not true, where the value of traded stocks negatively affects the velocity of money.

The response or elasticity of the value of traded stocks increases with the improvement in the level of economic development; this may be attributed to the high marginal propensity to save in the developed countries relative to the developed ones. 
The Velocity of Money and the Stock Market. A Comparative Forward ...

Dr. Ashraf Helmy Salama

Countries with high levels of money supply relative to their nominal GDP are experiencing a long-run negative impact running from the velocity of money to the value of traded stocks. This may be attributed to two main reasons; the accompanied high inflation rates increase the discount rates and decrease the prices of traded stocks. In addition, high inflation rates encourage the rates of consumption spending rather than the rates of investment spending.

In all cases, it can be said that the effect of the velocity of money on the traded stocks is much stronger than the effect of traded stocks on the velocity of money. The empirical findings of the study have been summarized in table (5).

Table (5): Summary of the Empirical Findings of the Study

\begin{tabular}{|l|c|c|c|c|}
\hline \multicolumn{5}{|c|}{ The Level of Money Supply to Nominal GDP } \\
\hline \multicolumn{1}{|c|}{ Classification } & $\begin{array}{c}\text { Dependent } \\
\text { Variable }\end{array}$ & $\begin{array}{c}\text { Independent } \\
\text { Variable }\end{array}$ & Elasticity & Coefficient \\
\hline $\begin{array}{l}\text { High levels of } \\
\text { money supply } \\
\text { relative to GDP }\end{array}$ & $\begin{array}{c}\text { The value of } \\
\text { traded stocks }\end{array}$ & $\begin{array}{c}\text { The velocity of } \\
\text { money }\end{array}$ & Elastic & -3.22 \\
\cline { 2 - 5 } & $\begin{array}{c}\text { The velocity of } \\
\text { money }\end{array}$ & $\begin{array}{c}\text { The value of } \\
\text { traded stocks }\end{array}$ & Inelastic & -0.08 \\
\hline $\begin{array}{l}\text { Low Levels of } \\
\text { relative to GDP }\end{array}$ & $\begin{array}{c}\text { The value of } \\
\text { traded stocks }\end{array}$ & $\begin{array}{c}\text { The velocity of } \\
\text { money }\end{array}$ & Elastic & 7.2 \\
\cline { 2 - 5 } & $\begin{array}{c}\text { The velocity of } \\
\text { money }\end{array}$ & $\begin{array}{c}\text { The value of } \\
\text { traded stocks }\end{array}$ & Inelastic & -0.24 \\
\hline \multicolumn{5}{|c|}{ The Level of Economic Development } \\
\hline \multicolumn{7}{|c|}{$\begin{array}{c}\text { Dependent } \\
\text { Variable }\end{array}$} & $\begin{array}{c}\text { Independent } \\
\text { Variable }\end{array}$ & Elasticity & Coefficient \\
\hline
\end{tabular}

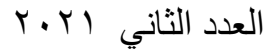

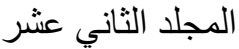


The Velocity of Money and the Stock Market. A Comparative Forward ...

Dr. Ashraf Helmy Salama

\begin{tabular}{|l|c|c|c|c|}
\hline $\begin{array}{l}\text { High Levels of } \\
\text { Development } \\
\text { (OECD) }\end{array}$ & $\begin{array}{c}\text { The value of } \\
\text { traded stocks }\end{array}$ & $\begin{array}{c}\text { The velocity of } \\
\text { money }\end{array}$ & Elastic & 14.8 \\
\cline { 2 - 5 } & $\begin{array}{c}\text { The velocity of } \\
\text { money }\end{array}$ & $\begin{array}{c}\text { The value of } \\
\text { traded stocks }\end{array}$ & Inelastic & 0.04 \\
\hline $\begin{array}{l}\text { Modest and low } \\
\text { levels of } \\
\text { Development }\end{array}$ & $\begin{array}{c}\text { The value of } \\
\text { traded stocks }\end{array}$ & $\begin{array}{c}\text { The velocity of } \\
\text { money }\end{array}$ & Elastic & 6.6 \\
\cline { 2 - 5 } & $\begin{array}{c}\text { The velocity of } \\
\text { money }\end{array}$ & $\begin{array}{c}\text { The value of } \\
\text { traded stocks }\end{array}$ & Inelastic & -0.06 \\
\hline
\end{tabular}

The above findings confirm the validity of the three hypotheses of the study.

The empirical findings illustrate that developing countries can make benefit from the high elasticity of the traded stocks to changes in the velocity of money through increasing the efficiency of different markets. In this regard, government regulations have to be directed to reduce different market externalities that impede the efficient performance of markets. On the other side, governments have to stop financing their activities and procurements through open market operations, which increase the pool of money supply and induce inflation. 
The Velocity of Money and the Stock Market. A Comparative Forward ...

Dr. Ashraf Helmy Salama

\section{Appendices}

Appendix (1)

Unit Root Test (Stationarity Test)

\begin{tabular}{|c|c|c|c|c|c|}
\hline \multicolumn{6}{|c|}{ Sample of Countries with Rates of Money Supply Exceed 100\% of Nominal GDP } \\
\hline \multirow[t]{2}{*}{ Variable } & \multirow{2}{*}{$\begin{array}{l}\text { Stationarity } \\
\text { Status }\end{array}$} & \multicolumn{2}{|c|}{$\begin{array}{c}\text { Augmented Dickey- } \\
\text { Fuller }\end{array}$} & \multicolumn{2}{|c|}{ Phillips-Perron } \\
\hline & & Statistic & Probability & Statistic & Probability \\
\hline \multirow{2}{*}{$\begin{array}{l}\text { The Value of } \\
\text { Traded Stocks }\end{array}$} & Level & 21.16 & 0.1724 & 19.1868 & 0.2591 \\
\hline & First Level & 58.4964 & 0 & 91.8357 & 0 \\
\hline \multirow{2}{*}{$\begin{array}{c}\text { The Velocity of } \\
\text { Money }\end{array}$} & Level & 5.81997 & 0.9899 & 27.9487 & 0.0321 \\
\hline & First Level & 67.7032 & 0 & 317.713 & 0 \\
\hline \multicolumn{6}{|c|}{ Sample of Countries with Rates of Money Supply 50\% or Less of Nominal GDP } \\
\hline \multirow[t]{2}{*}{ Variable } & \multirow{2}{*}{$\begin{array}{l}\text { Stationarity } \\
\text { Status }\end{array}$} & \multicolumn{2}{|c|}{$\begin{array}{c}\text { Augmented Dickey- } \\
\text { Fuller }\end{array}$} & \multicolumn{2}{|c|}{ Phillips-Perron } \\
\hline & & Statistic & Probability & Statistic & Probability \\
\hline \multirow{2}{*}{$\begin{array}{l}\text { The Value of } \\
\text { Traded Stocks }\end{array}$} & Level & 31.7237 & 0.0109 & 16.0415 & 0.4501 \\
\hline & First Level & 59.8352 & 0 & 74.3969 & 0 \\
\hline \multirow{2}{*}{$\begin{array}{c}\text { The Velocity of } \\
\text { Money }\end{array}$} & Level & 9.94564 & 0.8695 & 30.9384 & 0.0137 \\
\hline & First Level & 39.5811 & 0 & 98.7088 & 0 \\
\hline \multicolumn{6}{|c|}{ Sample of OECD Countries } \\
\hline \multirow[t]{2}{*}{ Variable } & \multirow{2}{*}{$\begin{array}{l}\text { Stationarity } \\
\text { Status }\end{array}$} & \multicolumn{2}{|c|}{$\begin{array}{c}\text { Augmented Dickey- } \\
\text { Fuller }\end{array}$} & \multicolumn{2}{|c|}{ Phillips-Perron } \\
\hline & & Statistic & Probability & Statistic & Probability \\
\hline \multirow{2}{*}{$\begin{array}{l}\text { The Value of } \\
\text { Traded Stocks }\end{array}$} & Level & 34.5279 & 0.0108 & 19.6225 & 0.3545 \\
\hline & First Level & 56.6902 & 0 & 88.7975 & 0 \\
\hline \multirow{2}{*}{$\begin{array}{c}\text { The Velocity of } \\
\text { Money }\end{array}$} & Level & 9.71447 & 0.9408 & 39.2185 & 0.0027 \\
\hline & First Level & 63.3167 & 0 & 310.944 & 0 \\
\hline \multicolumn{6}{|c|}{ Sample of Countries with Different Levels of Development } \\
\hline \multirow[t]{2}{*}{ Variable } & \multirow{2}{*}{$\begin{array}{l}\text { Stationarity } \\
\text { Status }\end{array}$} & \multicolumn{2}{|c|}{$\begin{array}{c}\text { Augmented Dickey- } \\
\text { Fuller }\end{array}$} & \multicolumn{2}{|c|}{ Phillips-Perron } \\
\hline & & Statistic & Probability & Statistic & Probability \\
\hline \multirow{2}{*}{$\begin{array}{l}\text { The Value of } \\
\text { Traded Stocks }\end{array}$} & Level & 54.0591 & 0.0158 & 36.2653 & 0.3634 \\
\hline & First Level & 118.286 & 0 & 163.090 & 0 \\
\hline
\end{tabular}

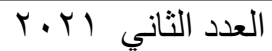

المجلد الثاني عشر 
The Velocity of Money and the Stock Market. A Comparative Forward ...

Dr. Ashraf Helmy Salama

\begin{tabular}{|c|c|c|c|c|c|}
\hline $\begin{array}{c}\text { The Velocity of } \\
\text { Money }\end{array}$ & Level & 20.1744 & 0.9710 & 63.8630 & 0.0014 \\
\cline { 2 - 6 } & First Level & 111.640 & 0 & 282.943 & 0 \\
\hline
\end{tabular}

\section{Appendix (2)}

Dependent Variable: $\mathrm{D}(\mathrm{Y})$

Method: ARDL

Sample: 20012019

Included observations: 152

Maximum dependent lags: 1 (Automatic selection)

Model selection method: Akaike info criterion (AIC)

Dynamic regressors (1 lag, automatic): $\mathrm{X}$

Fixed regressors: $\mathrm{C}$

Number of models evaluated: 1

Selected Model: ARDL $(1,1)$

\begin{tabular}{|c|c|c|c|c|}
\hline Variable & Coefficient & Std. Error & t-Statistic & Prob.* \\
\hline \multicolumn{5}{|c|}{ Long Run Equation } \\
\hline $\mathrm{X}$ & -3.226366 & 0.787707 & -4.095897 & 0.0001 \\
\hline \multicolumn{5}{|c|}{ Short Run Equation } \\
\hline COINTEQ01 & -0.264581 & 0.038813 & -6.816770 & 0.0000 \\
\hline $\mathrm{D}(\mathrm{X})$ & 0.095996 & 0.559677 & 0.171520 & 0.8641 \\
\hline $\mathrm{C}$ & 6.721500 & 1.047395 & 6.417352 & 0.0000 \\
\hline Mean dependent var & 0.081839 & \multicolumn{2}{|c|}{ S.D. dependent var } & 0.408287 \\
\hline S.E. of regression & 0.381371 & \multicolumn{2}{|c|}{ Akaike info criterion } & 0.851455 \\
\hline Sum squared resid & 19.63487 & \multicolumn{2}{|c|}{ Schwarz criterion } & 1.331951 \\
\hline Log likelihood & -43.11637 & \multicolumn{2}{|c|}{ Hannan-Quinn criter. } & 1.046567 \\
\hline
\end{tabular}

العدد الثاني (Y.r 
The Velocity of Money and the Stock Market. A Comparative Forward ...

Dr. Ashraf Helmy Salama

\section{Appendix (3)}

Dependent Variable: D(Y)

Method: ARDL

Sample: 20012019

Included observations: 152

Maximum dependent lags: 1 (Automatic selection)

Model selection method: Akaike info criterion (AIC)

Dynamic regressors (1 lag, automatic): $\mathrm{X}$

Fixed regressors: $\mathrm{C}$

Number of models evaluated: 1

Selected Model: ARDL $(1,1)$

\begin{tabular}{ccccc}
\hline \hline Variable & Coefficient & Std. Error & t-Statistic & Prob.* \\
\hline \hline \multicolumn{5}{c}{ Long Run Equation } \\
\hline X & -0.082856 & 0.013550 & -6.115016 & 0.0000 \\
\hline \hline \multicolumn{5}{c}{ Short Run Equation } \\
COINTEQ01 & -0.329017 & 0.076202 & -4.317717 & 0.0000 \\
D $(X)$ & 0.023969 & 0.017382 & 1.378944 & 0.1702 \\
C & 0.612295 & 0.161752 & 3.785385 & 0.0002 \\
\hline \hline Mean dependent var & -0.014215 & S.D. dependent var & 0.064674 \\
S.E. of regression & 0.047882 & Akaike info criterion & -2.953362 \\
Sum squared resid & 0.309516 & Schwarz criterion & -2.472866 \\
Log likelihood & 261.2690 & Hannan-Quinn criter. & -2.758250 \\
\hline \hline
\end{tabular}


The Velocity of Money and the Stock Market. A Comparative Forward ...

Dr. Ashraf Helmy Salama

\section{Appendix (4)}

Dependent Variable: D(Y)

Method: ARDL

Sample: 20012019

Included observations: 152

Maximum dependent lags: 1 (Automatic selection)

Model selection method: Akaike info criterion (AIC)

Dynamic regressors (1 lag, automatic): X

Fixed regressors: $\mathrm{C}$

Number of models evaluated: 1

Selected Model: ARDL $(1,1)$

\begin{tabular}{|c|c|c|c|c|}
\hline Variable & Coefficient & Std. Error & $\mathrm{t}$-Statistic & Prob.* \\
\hline \multicolumn{5}{|c|}{ Long Run Equation } \\
\hline \multirow[t]{2}{*}{$X$} & 7.211908 & 0.970838 & 7.428539 & 0.0000 \\
\hline & \multicolumn{3}{|c|}{ Short Run Equation } & \\
\hline COINTEQ01 & -0.145866 & 0.062718 & -2.325762 & 0.0215 \\
\hline $\mathrm{D}(\mathrm{X})$ & -0.182398 & 0.483646 & -0.377132 & 0.7067 \\
\hline $\mathrm{C}$ & 2.621025 & 1.153665 & 2.271912 & 0.0247 \\
\hline Mean dependent var & 0.069661 & \multicolumn{2}{|c|}{ S.D. dependent var } & 0.451766 \\
\hline S.E. of regression & 0.424541 & \multicolumn{2}{|c|}{ Akaike info criterion } & 1.105144 \\
\hline Sum squared resid & 24.33169 & \multicolumn{2}{|c|}{ Schwarz criterion } & 1.585640 \\
\hline Log likelihood & -63.41153 & \multicolumn{2}{|c|}{ Hannan-Quinn criter. } & 1.300257 \\
\hline
\end{tabular}


The Velocity of Money and the Stock Market. A Comparative Forward ...

Dr. Ashraf Helmy Salama

\section{Appendix (5)}

Dependent Variable: D(Y)

Method: ARDL

Sample: 20012019

Included observations: 152

Maximum dependent lags: 1 (Automatic selection)

Model selection method: Akaike info criterion (AIC)

Dynamic regressors (1 lag, automatic): X

Fixed regressors: $\mathrm{C}$

Number of models evaluated: 1

Selected Model: ARDL $(1,1)$

\begin{tabular}{ccccc}
\hline \hline Variable & Coefficient & Std. Error & t-Statistic & Prob.* \\
\hline \hline \multicolumn{5}{c}{ Long Run Equation } \\
\hline \hline \multicolumn{5}{c}{ Short Run Equation } \\
\hline \hline X & -0.246512 & 0.032594 & -7.563224 & 0.0000 \\
\hline \hline COINTEQ01 & -0.157575 & 0.051473 & -3.061288 & 0.0027 \\
D $(X)$ & 0.050419 & 0.024587 & 2.050623 & 0.0422 \\
C & 1.066117 & 0.376128 & 2.834455 & 0.0053 \\
\hline \hline Mean dependent var & -0.025250 & S.D. dependent var & 0.065855 \\
S.E. of regression & 0.054827 & Akaike info criterion & -2.890318 \\
Sum squared resid & 0.405815 & Schwarz criterion & -2.409822 \\
Log likelihood & 256.2254 & Hannan-Quinn criter. & -2.695205 \\
\hline \hline
\end{tabular}


The Velocity of Money and the Stock Market. A Comparative Forward ...

Dr. Ashraf Helmy Salama

\section{Appendix (6)}

Dependent Variable: D(Y)

Method: ARDL

Sample: 20012019

Included observations: 171

Maximum dependent lags: 1 (Automatic selection)

Model selection method: Akaike info criterion (AIC)

Dynamic regressors (1 lag, automatic): $\mathrm{X}$

Fixed regressors: $\mathrm{C}$

Number of models evaluated: 1

Selected Model: ARDL $(1,1)$

\begin{tabular}{|c|c|c|c|c|}
\hline Variable & Coefficient & Std. Error & t-Statistic & Prob.* \\
\hline \multicolumn{5}{|c|}{ Long Run Equation } \\
\hline $\mathrm{X}$ & 14.84256 & 4.279949 & 3.467928 & 0.0007 \\
\hline \multicolumn{5}{|c|}{ Short Run Equation } \\
\hline COINTEQ01 & -0.035263 & 0.035849 & -0.983640 & 0.3269 \\
\hline $\mathrm{D}(\mathrm{X})$ & 0.397360 & 0.471509 & 0.842741 & 0.4007 \\
\hline $\mathrm{C}$ & 0.859545 & 0.779751 & 1.102332 & 0.2721 \\
\hline Mean dependent var & 0.057079 & \multicolumn{2}{|c|}{ S.D. dependent var } & 0.324837 \\
\hline S.E. of regression & 0.293471 & \multicolumn{2}{|c|}{ Akaike info criterion } & 0.466928 \\
\hline Sum squared resid & 13.09106 & \multicolumn{2}{|c|}{ Schwarz criterion } & 0.963610 \\
\hline Log likelihood & -14.02351 & \multicolumn{2}{|c|}{ Hannan-Quinn criter. } & 0.668311 \\
\hline
\end{tabular}


The Velocity of Money and the Stock Market. A Comparative Forward ...

Dr. Ashraf Helmy Salama

\section{Appendix (7)}

Dependent Variable: D(Y)

Method: ARDL

Sample: 20012019

Included observations: 171

Maximum dependent lags: 1 (Automatic selection)

Model selection method: Akaike info criterion (AIC)

Dynamic regressors (1 lag, automatic): Y

Fixed regressors: $\mathrm{C}$

Number of models evaluated: 1

Selected Model: ARDL $(1,1)$

\begin{tabular}{ccccc}
\hline \hline Variable & Coefficient & Std. Error & t-Statistic & \multirow{2}{*}{ Prob.* } \\
\hline \hline \multicolumn{5}{c}{ Long Run Equation } \\
\hline \hline X & 0.047745 & 0.013459 & 3.547474 & 0.0005 \\
\hline \hline \multicolumn{5}{c}{ Short Run Equation } \\
\hline \hline COINTEQ01 & -0.252607 & 0.107428 & -2.351411 & 0.0200 \\
D $(X)$ & 0.031526 & 0.019463 & 1.619743 & 0.1074 \\
C & -0.281360 & 0.111666 & -2.519644 & 0.0128 \\
\hline \hline Mean dependent var & -0.024223 & S.D. dependent var & 0.078159 \\
S.E. of regression & 0.053948 & Akaike info criterion & -2.849178 \\
Sum squared resid & 0.442376 & Schwarz criterion & -2.352496 \\
Log likelihood & 284.4260 & Hannan-Quinn criter. & -2.647795 \\
\hline \hline
\end{tabular}


The Velocity of Money and the Stock Market. A Comparative Forward ...

Dr. Ashraf Helmy Salama

\section{Appendix (8)}

Dependent Variable: D(Y)

Method: ARDL

Sample: 20012019

Included observations: 171

Maximum dependent lags: 1 (Automatic selection)

Model selection method: Akaike info criterion (AIC)

Dynamic regressors (1 lag, automatic): $\mathrm{X}$

Fixed regressors: $\mathrm{C}$

Number of models evaluated: 1

Selected Model: ARDL $(1,1)$

\begin{tabular}{ccccc}
\hline \hline Variable & Coefficient & Std. Error & t-Statistic & Prob.* \\
\hline \hline \multicolumn{5}{c}{ Long Run Equation } \\
\hline X & 6.655373 & 1.066504 & 6.240366 & 0.0000 \\
\hline \hline \multicolumn{5}{c}{ Short Run Equation } \\
COINTEQ01 & -0.124079 & 0.028690 & -4.324872 & 0.0000 \\
D $(\mathrm{X})$ & -0.358143 & 0.373680 & -0.958423 & 0.3387 \\
$\mathrm{C}$ & 2.662937 & 0.546077 & 4.876489 & 0.0000 \\
\hline \hline Mean dependent var & 0.076515 & S.D. dependent var & 0.437790 \\
S.E. of regression & 0.423394 & Akaike info criterion & 1.118870 \\
Sum squared resid & 51.62753 & Schwarz criterion & 1.704474 \\
Log likelihood & -138.2079 & Hannan-Quinn criter. & 1.352208 \\
\hline \hline
\end{tabular}


The Velocity of Money and the Stock Market. A Comparative Forward ...

Dr. Ashraf Helmy Salama

\section{Appendix (9)}

Dependent Variable: D(Y)

Method: ARDL

Sample: 20012019

Included observations: 171

Maximum dependent lags: 1 (Automatic selection)

Model selection method: Akaike info criterion (AIC)

Dynamic regressors (1 lag, automatic): $\mathrm{X}$

Fixed regressors: $\mathrm{C}$

Number of models evaluated: 1

Selected Model: ARDL $(1,1)$

\begin{tabular}{ccccc}
\hline \hline Variable & Coefficient & Std. Error & t-Statistic & Prob.* \\
\hline \hline \multicolumn{5}{c}{ Long Run Equation } \\
\hline \hline X & -0.066892 & 0.011703 & -5.715986 & 0.0000 \\
\hline \hline \multicolumn{5}{c}{ Short Run Equation } \\
COINTEQ01 & -0.225836 & 0.035937 & -6.284271 & 0.0000 \\
D $(\mathrm{X})$ & 0.020062 & 0.007177 & 2.795459 & 0.0055 \\
$\mathrm{C}$ & 0.384216 & 0.056479 & 6.802786 & 0.0000 \\
\hline \hline Mean dependent var & -0.018689 & S.D. dependent var & 0.058279 \\
S.E. of regression & 0.051545 & Akaike info criterion & -2.901396 \\
Sum squared resid & 0.765174 & Schwarz criterion & -2.315793 \\
Log likelihood & 545.2374 & Hannan-Quinn criter. & -2.668058 \\
\hline \hline
\end{tabular}


The Velocity of Money and the Stock Market. A Comparative Forward ...

Dr. Ashraf Helmy Salama

\section{References}

Akinlo, A. (2012). Financial Development and the Velocity of Money in

Nigeria: An Empirical Analysis. The review of Finance and Banking. Vol. 4, No. 2, pp 97 -113

Akinlo, A. (2012). Financial Development and the Velocity of Money in

Nigeria: An Empirical Analysis. The Review of Finance and Banking,

Academia de Studii Economice din Bucuresti, Romania / Facultatea de

Finante, Asigurari, Banci si Burse de Valori / Catedra de Finante, vol. 4(2), pages 97-113.

Alikhanov, M., \& Taylor, L. (2015). Real or nominal shock which one does more to destabilize developing economies? The Case of Money Velocity in Kazakhstan. Bulgarian Economic Papers bep-2015-06, Faculty of Economics and Business Administration, Sofia University

St Kliment Ohridski- Bulgaria. Center for Economic Theories and Policies at Sofia University St Kliment Ohridski.

Aruna, A. (2016). Velocity of Money within the Framework of Monetary Targeting in Sierra Leone. West African Journal of Monetary and Economic Integration, West African Monetary Institute, vol. 16(1), pages 62-96.

Baumol, W., \& Blinder, A. (2003). Economics--principles and policy/

William J. Baumol, Alan S. Blinder. ( $9^{\text {th }}$ ed.). South-Western.

Friedman, B. (1984), Lessons from the 1979-1982 monetary policy experiment. The American Economic Review Papers and Proceedings, 74, 397-400. DOI: https://doi.org/10.3386/w1272

Gentle, P.F., \& Jones, J. (2015). Reflections Concerning the Money

Supply, Velocity, and the Quantity Theory of Money: The Great

Depression and the Great Recession, in the United States. Banks and

Bank Systems, Vol. 10, issue 2, Pages 72-82.

Komijani, A., \& Nazarian, R. (2004). Behavioral Pattern of Income 
The Velocity of Money and the Stock Market. A Comparative Forward ...

Dr. Ashraf Helmy Salama

Velocity of Money and Estimation of Its Function (The case of Iran). Iranian Economic Review, 11, 21-56. DOI: 10.22059/ier.2004.30910 LEÃO, P. (2005). Why does the velocity of money move pro- cyclically? International Review of Applied Economics, Vol.19(1), pages 119135. doi:10.1080/0269217042000312641

Mohamed, E. (2020). Velocity of Money Income and Economic Growth in Sudan: Cointegration and Error Correction Analysis. International Journal of Economics and Financial Issues, 10, 87-98. DOI: https://doi.org/10.32479/ijefi.8944

Mujeri M.K., Mujeri N. (2020). Bangladesh at Fifty: Moving beyond Development Traps. Palgrave Studies in Economic History. Palgrave Macmillan, Cham. DOI: https://doi.org/10.1007/978-3-030-56791-0_9 Nampewo, D., \& Opolot, J. (2016). Financial Innovations and Money Velocity in Uganda. African Development Review, 28(4), 371-382. doi:10.1111/1467-8268.12218

Ng'imor, B.P. (2015). The Impact of Financial Development on Income Velocity of Money in Kenya. International Journal of Development Research. Vol. 5, Issue, 02, pp. 3522-3534.

Nunes, A., Aubyn, M.S., Valério, N., \& Sousa, R. (2018). Determinants of the income velocity of money in Portugal: 1891-1998. Portuguese Economic Journal, 17, 99-115. DOI: https://doi.org/10.1007/s10258017-0141-1

Okafor, P.N., Shitile, T.S., Osude, D., Ihediwa, C.C., Owolabi, O.H., Shom, V.C., \& Agbadaola, E.T. (2013). Determinants of income velocity of money in Nigeria. Central Bank of Nigeria Economic and Financial Review Volume 51/1.

Rami, G. 2010. Velocity of Money functions in India: Analysis and Interpretations. Quest-Journal of Management and Research, Vol 1, Issue 1, June 2010. Pages 15-26. DOI: 10.2139/ssrn.1783473. 
The Velocity of Money and the Stock Market. A Comparative Forward ...

Dr. Ashraf Helmy Salama

Sharma, S., \& Syarifuddin, F. (2019). Determinants of Indonesia's Incomes Velocity of Money. Bulletin of Monetary Economics and Banking, Volume 21, Number 3. P 323-342. DOI: https://doi.org/10.21098/bemp.v21i3.1006

Sudo, N. (2011). Accounting for the Decline in the Velocity of Money in the Japanese Economy. IMES Discussion Paper Series 11-E-16, Institute for Monetary and Economic Studies, Bank of Japan.

Warburton, C. (2013). When Markets Fail: Asset Prices, Government Expenditures, and the Velocity of Money. Applied Econometrics and International Development, 13, 73-92.

Westerhoff, F. (2011). Interactions between the Real Economy and the Stock Market: A Simple Agent-Based Approach. Discrete Dynamics in Nature and Society, 2012, 1-21. DOI: https://doi.org/10.1155/2012/504840

Yua, H. (2013). Review of the Studies on the China's Velocity of Money Influencing Factors. Journal of Hubei University of Education.

Zhao, L., \& Wang, Y. (2006). Determinates of The Decline in The Income-Velocity of Money in China: A New Perspective. Frontiers of Economics in China, 1(2), 256-271. DOI:10.1007/s11459-006-0008-3 